\title{
Effect of some Plant Extracts on Sugar Beet Powdery Mildew
}

M.S. Abd-Rabboh* and M. Z. El-

Shennawy**

* Plant Pathol. Res. Inst. Agric. Res. Centre, Giza, Egypt.

** Agric. Botany Dept., Fac. Agric., Menoufiya Univ., Egypt.

\begin{abstract}
his work was carried out under field conditions of two Governorates i.e. Menoufiya and Giza, during two successive sugar beet growing seasons (2013/14 and 2014/15). The efficacy of using extracts of four medicinal and aromatic plants, i.e. Fennel, Rosemary, Marjoram and Thyme extract by three organic solvents (ethanol, petroleum ether and chloroform) on the disease severity of sugar beet powdery mildew was studied. All treatments significantly reduced the disease severity of powdery mildew disease. Rosemary ethanol extract was the best treatment in reducing disease severity in the both seasons at the two governorate followed by fennal ethanol extract. On the other hand, marjoram petroleum ether extract was the least effective one. Also, the application of these treatments increased some crop parameters, i.e. total soluble solids (T.S.S), sucrose percent in root, purity of sugar and root weight.
\end{abstract}

Keywords: Sugar beet, powdery mildew and plant extracts.

Sugar beet (Beta vulgaris L.) is one of the most important sugar crops. It occupied the second group after sugar cane in producing sugar. Several pathogenic fungi attack growing sugar beet plants causing considerable loss in sugar yield. Cercospora leaf spot, powdery mildew and rust are the most serious and destructive foliar diseases in many sugar beet growing regions of the world (El-Kholi, 2000).

Sugar beet powdery mildew caused by Erysiphe betae Vanha weltzien is one of the most important foliar diseases in many sugar beet growing countries. In the conditions of high disease pressure and in the absence of control measures, the losses in sugar yield may reach up to $30 \%$ (Gado, 2013). Unfortunately, the overzealous and indiscriminate use of the fungicides to control plant diseases have many undesirable attributes, including pesticide residues, negative impact on the environment (water, soil, animals and food contamination) development of fungicidal resistant strains and the adverse effects on non-target organisms (Brimner and Boland, 2003). To minimize the concerns of these issues, alternative methods should be used to control plant diseases.

Biological fungicides, being plant products are easily convertible into a common organic material and may create fewer health problems compared to chemical fungicides. Use of plant extracts and phyto-products is gaining attention due to their biodegradability and minimum residual toxicity in the ecosystem (Ogobo and Oyibo, 2008). Rosemary crude leaf ethanolic extract reduced the radial mycelia growth as well as sclerotial production of Sclerotinia sclerotiorum (Goussous et al., 2013). 
Alsurhanee (2003) found that, spraying squash in greenhouse and field with extracts (acetone, methanol and petroleum ether) for anise seeds, blue gum leaves, chamomile flowers, cumin seeds, marjoram herb and thyme herb gave sufficient control to squash powdery mildew disease in most cases. Neetu et al. (2013) reported that, aqueous and alcoholic seed extracts of Foeniculum vulgare were effective against Alternaria alternata and Mucor rouxii in vitro test.

The objective of our research aims to study the effect of three organic solvent extracts (Ethanol, Pertoliumether and Chloroform) of four medicinal and aromatic plants (Fennel, Foenicum vulgare; Marjoram, Origanum majorna; Thyme, Thymus vulgaris and Rosemary, Rosmarinus officinals) on sugar beet powdery mildew disease severity under field conditions.

\section{Mat erials and Methods}

Plant materials and preparation of solvent extract:

Four aromatic and medicinal plants, Fennel (Foeniculum vulgare, M.) Rosemary (Rosmarinus officinalis L.), Marjoram (Origanum majorana L.) and Thyme (Thymus vulgaris L.) were obtained from the Horticultural Department, Faculty of Agriculture, Menoufiya University, Shibin El-Kom, Egypt. Plants were washed with distilled water and dried in shade. After 2 weeks the dried plant materials were finally grinded to powder. Extracts were prepared using the sequencing extraction methods using three organic solvents Ethanol, Petroleum ether and Chloroform. Fifty grams sample of fine powder from each plant were homogenized by laboratory blender in $200 \mathrm{ml}$ of ethanol (98\%) and distilled water $(20: 80, \mathrm{v}: \mathrm{v})$ for $10 \mathrm{~min}$, then left in dark glass bottles for $72 \mathrm{~h}$ for tissue maceration. The extract was filtered through thin cheesecloth sheet. The final extracts were collected separately in other dark glass bottles and exposed to $60^{\circ} \mathrm{C}$ in a water bath for $30 \mathrm{~min}$ for ethanol evaporation then distilled water was added to the collected extracts to prepare $5 \%$ concentration. The remaining treated powder from the first solvent was left on tissue paper at room temperature to dry totally again from the solvent. Then re-extracted by Petroleum ether for 48 hours and follow the same steps. The same steps were done using the same treated powder after drying with chloroform. Then extractions were stored in a refrigerator at $5^{\circ} \mathrm{C}$ for further studies (El-Mougy and Mokhtar, 2007).

Evaluation of five sugar beet cultivars to powdery mildew disease:

Five sugar beet cultivars obtained from sugar crops research institute, A.R.C. Giza, Egypt were evaluated for their reaction to powdery mildew disease caused by Erysiphe betae under field conditions during winter season 2012/2013. The tested cultivars were Nijma, Mamoth, Pleno, Rita and Habiba. Field was divided into five plots. Rows were sown by sugar beet seeds $30 \mathrm{~cm}$ apart (12 rows / plot). Field was irrigated as needed and agricultural practices were done as usual. After four months, 15 plants from each cultivar were randomly chosen for determination of disease severity, disease incidence $\%$, root weight and sucrose $\%$. The percentage of disease incidence was recorded using the formula: Disease incidence $(\%)=$ No. of diseased plants $/$ Total No. of plants assessed $\times 100$ 
Disease severity was determined according to the modified scale suggested by Whitney et al. (1983) as follows: $0=$ no mildew colonies observed, $1=<1-25 \%, 2$ $=<25-50 \%, 3=<50-75 \%$ and $4=<76-100 \%$ of matured leaf area covered by mildew. In addition, some yield component parameter, i.e. roots weight $(\mathrm{kg})$, total soluble solids (T.S.S) \% was measured in fresh roots using the hand refractometer according to McGinnis (1982). Sucrose \% was determined according to Anon. (1990). Purity \% was calculated by using the formula:

$$
\text { Purity } \%=\text { Sucrose } \% / \text { TSS \% x } 100
$$

Effect of organic solvent extracts of four medicinal and aromatic plants on powdery mildew disease severity:

Experiments were carried out at experimental farm, Faculty of Agric., Menoufiya Univ., Shibin El-Kom and the farm of ARC, Giza during two agricultural seasons 2013/2014 and 2014/2015 (four replicates for each treatment) in completely randomized design. Filed was divided into 4 plots. Each plot includes 14 rows (3 m in length and $50 \mathrm{~cm}$ width). Plots were sown by sugar beet seeds $30 \mathrm{~cm}$ a part (Nijma cv.). The normal methods of agricultural practices were done. Plants were sprayed with plant extracts and fungicide Domark (10\% EC) at the recommended dose $40 \mathrm{~cm}^{3} / 100 \mathrm{~L}$ water, three times at three weeks intervals started when the first sign of disease was appeared. At harvest, 10 plants were randomly collected for determination of disease severity, root weight, sucrose $\%$, purity of sugar $\%$ and T.S.S.

\section{Statistical analysis:}

Data obtained were subjected to analysis of variance (ANOVA) using CoStat Software, Version 6.4 (2008). The mean differences were compared to Duncan's Multiple Range Test (DMRT) according to Winer (1971).

\section{Res u l t s}

Data in Table (1) show that disease severity and disease incidence were differed with sugar beet cultivars. Nijma was the highest susceptible cultivar in the two governorates. It's exhibited 2.9 and $48.3 \%, 2.8$ and $46.7 \%$ for disease incidence and disease severity in Giza and Menoufiya, respectively. On the other hand, Habiba cultivar was the lowest susceptible cultivar in the two governorates. The disease incidence and the disease severity were 1.5 and $30.0 \%, 1.6$ and $38.3 \%$, respectively in Giza and Menoufiya governorates.

Table 1. Reaction of five sugar beet cultivars to powdery mildew disease

\begin{tabular}{|l|c|c|c|c|}
\hline \multirow{2}{*}{ Cultivar } & \multicolumn{2}{|c|}{ Giza } & \multicolumn{2}{c|}{ Menoufiya } \\
\cline { 2 - 5 } & $\begin{array}{c}\text { Disease } \\
\text { incidence (\%) }\end{array}$ & $\begin{array}{c}\text { Disease } \\
\text { severity (\%) }\end{array}$ & $\begin{array}{c}\text { Disease } \\
\text { incidence (\%) }\end{array}$ & $\begin{array}{c}\text { Disease } \\
\text { severity (\%) }\end{array}$ \\
\hline Nijma & 48.3 & 2.9 & 46.7 & 2.8 \\
Mammoth & 38.3 & 2.2 & 36.7 & 2.1 \\
Pleno & 36.7 & 1.9 & 35.0 & 1.8 \\
Rita & 36.7 & 2.0 & 33.3 & 1.9 \\
Habiba & 30.0 & 1.5 & 28.3 & 1.6 \\
\hline
\end{tabular}


Data in Table (2) indicate that, the application of plant extracts and one fungicide significantly reduced the percentage of disease severity during the two seasons compared to the control in Menoufiya governorate. The fungicide Domark $(10 \% \mathrm{EC})$ was superior in reducing the disease severity in both seasons tested. The corresponding reduction percentages in disease severity were $73.0 \%$ and $82.6 \%$, respectively. Among all organic solvent tested rosemary ethanol extract was the most effective one, as it reduced disease severity with $65.3 \%$ and $73.9 \%$, respectively. While marjoram, chloroform extract was the lowest effective one $(34.6 \%)$ reduction in disease severity during seasons 2013/2014. Meanwhile, during seasons 2014/2015 marjoram extract with petroleum ether gave the lowest reduction in disease severity being $21.7 \%$.

Table 2. Effect of some plant extracts and Domark fungicide on powdery mildew disease severity under field conditions in Menoufiya governorate

\begin{tabular}{|c|c|c|c|c|c|}
\hline \multirow[b]{2}{*}{ Treatment } & \multirow{2}{*}{$\begin{array}{l}\text { Solvent* } \\
\text { used in } \\
\text { extraction }\end{array}$} & \multicolumn{2}{|c|}{ 2013/14 Season } & \multicolumn{2}{|c|}{ 2014/15 Season } \\
\hline & & $\begin{array}{l}\text { Disease } \\
\text { severity }\end{array}$ & $\begin{array}{c}\text { Reduction** } \\
(\%)\end{array}$ & $\begin{array}{l}\text { Disease } \\
\text { severity }\end{array}$ & $\begin{array}{c}\text { Reduction ** } \\
(\%)\end{array}$ \\
\hline \multirow{3}{*}{ Marjoram } & $\mathrm{A}$ & $1.6^{\mathrm{bc}}$ & 38.4 & $1.8^{\mathrm{b}}$ & 21.7 \\
\hline & B & $1.7^{\mathrm{b}}$ & 34.6 & $1.7^{\mathrm{bc}}$ & 26.1 \\
\hline & $\mathrm{C}$ & $1.5^{\mathrm{cd}}$ & 42.3 & $1.6^{\mathrm{cd}}$ & 30.4 \\
\hline \multirow{3}{*}{ Thyme } & A & $1.5^{\mathrm{cd}}$ & 42.3 & $1.7^{\mathrm{bc}}$ & 26.1 \\
\hline & B & $1.6^{\mathrm{bc}}$ & 38.4 & $1.6^{\mathrm{cd}}$ & 30.4 \\
\hline & $\mathrm{C}$ & $1.4^{\mathrm{de}}$ & 46.1 & $1.5^{\mathrm{de}}$ & 34.8 \\
\hline \multirow{3}{*}{ Fennel } & A & $1.3^{\mathrm{ef}}$ & 50.0 & $1.4^{\mathrm{ef}}$ & 39.1 \\
\hline & B & $1.4^{\mathrm{de}}$ & 46.1 & $1.4^{\mathrm{ef}}$ & 39.1 \\
\hline & $\mathrm{C}$ & $1.2^{\mathrm{f}}$ & 53.8 & $1.3^{\mathrm{f}}$ & 43.5 \\
\hline \multirow{3}{*}{ Rosemary } & $\bar{A}$ & $1.0^{\mathrm{g}}$ & 61.5 & $1.1^{\mathrm{g}}$ & 52.2 \\
\hline & $\mathrm{B}$ & $0.9^{\mathrm{g}}$ & 65.3 & $0.9^{\mathrm{h}}$ & 60.9 \\
\hline & $\mathrm{C}$ & $0.9^{\mathrm{g}}$ & 65.3 & $0.6^{\mathrm{i}}$ & 73.9 \\
\hline \multicolumn{2}{|c|}{ Domark (10\% EC) } & $0.7^{\mathrm{h}}$ & 73.0 & $0.4^{j}$ & 82.6 \\
\hline \multicolumn{2}{|c|}{ Control } & $2.6^{\mathrm{a}}$ & - & $2.3^{\mathrm{a}}$ & - \\
\hline
\end{tabular}

* Solvent: Petroleum ether (A), Chloroform (B), Ethanol (C).

** Reduction in disease severity $(\%)=\frac{\frac{\mathrm{C}}{\mathrm{C}} \mathrm{T}}{\mathrm{C}} \times 100$

$\mathrm{C}=$ Disease severity of the control treatment. $\mathrm{T}=$ Disease severity of the treatment used.

- Duncan's multiple range tests was used-values followed by the different letters are significantly differed from each other.

Results presented in Table (3) show that, all treatments sharply decreased the disease severity in both seasons tested in Giza governorate. The high reduction in disease severity was obtained due to application of rosemary ethanolic extract in the both seasons tested being $70.96 \%$ and $68.96 \%$, respectively. On the other hand, marjoram petroleum ether extract gave the lowest effect in reducing disease severity compared with other tested treatments $(35.48 \%$ and $31.03 \%$, respectively). Data in Tables (4 and 5) clearly show that all treatments led to considerable increase in some crop parameters, i.e. root weight $(\mathrm{kg})$, sucrose $(\%)$, T.S.S (\%) and purity of sugar (\%) comparing to control in the both seasons in the two tested governorates. The highest 
increases in the studied crop parameters were obtained by application with Domark fungicide followed by rosemary ethanol extract, while application with Marjoram petroleum ether extract gave the lowest increases followed by marjoram chloroform extract.

Table 3. Effect of some plant extracts and Domark fungicide on powdery mildew disease severity under field conditions in Giza governorate

\begin{tabular}{|c|c|c|c|c|c|}
\hline \multirow[b]{2}{*}{ Treatment } & \multirow{2}{*}{$\begin{array}{l}\text { Solvent* } \\
\text { used in } \\
\text { extraction }\end{array}$} & \multicolumn{2}{|c|}{ 2013/2014 Season } & \multicolumn{2}{|c|}{ 2014/2015 Season } \\
\hline & & $\begin{array}{l}\text { Disease } \\
\text { severity }\end{array}$ & $\begin{array}{c}\text { Reduction** } \\
(\%)\end{array}$ & $\begin{array}{l}\text { Disease } \\
\text { severity }\end{array}$ & $\begin{array}{c}\text { Reduction** } \\
(\%)\end{array}$ \\
\hline \multirow{3}{*}{ Marjoram } & $\mathrm{A}$ & $2.0^{\mathrm{b}}$ & 35.5 & $2.0^{\mathrm{b}}$ & 31.0 \\
\hline & B & $1.9^{\mathrm{bc}}$ & 38.7 & $1.9^{\mathrm{bc}}$ & 34.5 \\
\hline & $\mathrm{C}$ & $1.8^{\mathrm{cd}}$ & 41.9 & $1.8^{\mathrm{cd}}$ & 37.9 \\
\hline \multirow{3}{*}{ Thyme } & $\bar{A}$ & $1.8^{\mathrm{cd}}$ & 41.9 & $1.8^{\mathrm{cd}}$ & 37.9 \\
\hline & B & $1.7^{\mathrm{de}}$ & 45.2 & $1.7^{\mathrm{de}}$ & 41.4 \\
\hline & $\mathrm{C}$ & $1.6^{\mathrm{ef}}$ & 48.4 & $1.7^{\mathrm{de}}$ & 41.4 \\
\hline \multirow{3}{*}{ Fennel } & A & $1.6^{\mathrm{ef}}$ & 48.4 & $1.6^{\mathrm{ef}}$ & 44.8 \\
\hline & B & $1.5^{\mathrm{fg}}$ & 51.6 & $1.6^{\mathrm{ef}}$ & 44.8 \\
\hline & $\mathrm{C}$ & $1.4^{\mathrm{gh}}$ & 54.8 & $1.5^{\mathrm{f}}$ & 48.3 \\
\hline \multirow{3}{*}{ Rosemary } & A & $1.3^{\text {hi }}$ & 58.1 & $1.2^{\mathrm{g}}$ & 58.6 \\
\hline & B & $1.2^{\mathrm{i}}$ & 61.3 & $1.2^{\mathrm{g}}$ & 58.6 \\
\hline & $\mathrm{C}$ & $0.9^{\mathrm{j}}$ & 71.0 & $0.9^{\mathrm{h}}$ & 69.0 \\
\hline \multicolumn{2}{|c|}{ Domark (10\% EC) } & $0.5^{\mathrm{k}}$ & 83.87 & $0.6^{i}$ & 79.31 \\
\hline \multicolumn{2}{|c|}{ Control } & $3.1^{\mathrm{a}}$ & - & $2.9^{\mathrm{a}}$ & - \\
\hline
\end{tabular}

$(*) \&(* *)$ as described in footnote of Table (2).

Table 4. Effect of plant extracts with different organic solvents on some crop parameters of sugar beet in Menoufiya governorate

\begin{tabular}{|c|c|c|c|c|c|c|c|c|c|}
\hline \multirow[b]{2}{*}{ Treatment } & \multirow{2}{*}{$\begin{array}{l}\stackrel{*}{*} \\
\bar{D} \\
\stackrel{ \pm}{0} \\
\infty\end{array}$} & \multicolumn{4}{|c|}{ 2013/14 Season } & \multicolumn{4}{|c|}{ 2014/15 Season } \\
\hline & & $\begin{array}{c}\text { Root } \\
\text { weight }(\mathrm{Kg})\end{array}$ & $\begin{array}{c}\text { Sucrose } \\
(\%)\end{array}$ & $\begin{array}{c}\text { T.S.S } \\
(\%)\end{array}$ & $\begin{array}{c}\text { Purity } \\
(\%)\end{array}$ & $\begin{array}{c}\text { Root } \\
\text { weight }(\mathrm{Kg})\end{array}$ & $\begin{array}{c}\text { Sucrose } \\
(\%)\end{array}$ & $\begin{array}{c}\text { T.S.S } \\
(\%)\end{array}$ & $\begin{array}{c}\text { Purity } \\
(\%)\end{array}$ \\
\hline \multirow{3}{*}{ Marjoram } & $\mathrm{A}$ & $1.0^{\mathrm{g}}$ & $12.6^{i}$ & $18.0^{\mathrm{h}}$ & $70.0^{\mathrm{k}}$ & $1.0^{\mathrm{g}}$ & $13.7^{1}$ & $19.3^{\mathrm{g}}$ & $70.8^{\mathrm{k}}$ \\
\hline & $\mathrm{B}$ & $1.1^{\mathrm{fg}}$ & $12.9^{\mathrm{h}}$ & $18.4^{\mathrm{g}}$ & $70.1^{\mathrm{k}}$ & $1.2^{\mathrm{f}}$ & $13.8^{\mathrm{hi}}$ & $19.4^{\mathrm{g}}$ & $71.0^{\mathrm{j}}$ \\
\hline & $\mathrm{C}$ & $1.1^{\mathrm{efg}}$ & $13.0^{\mathrm{h}}$ & $18.4^{\mathrm{g}}$ & $70.7^{\mathrm{j}}$ & $1.3^{\text {ef }}$ & $13.9^{\mathrm{h}}$ & $19.5^{\mathrm{g}}$ & $71.3^{\mathrm{i}}$ \\
\hline \multirow{3}{*}{ Thyme } & $\mathrm{A}$ & $1.1^{\operatorname{defg}}$ & $13.3^{\mathrm{g}}$ & $18.4^{\mathrm{g}}$ & $72.1^{i}$ & $1.3^{\mathrm{ef}}$ & $15.0^{\mathrm{g}}$ & $20.8^{\mathrm{f}}$ & $72.0^{\mathrm{h}}$ \\
\hline & $\mathrm{B}$ & $1.2^{\text {bcdef }}$ & $13.6^{\mathrm{f}}$ & $18.7^{\mathrm{f}}$ & $72.5^{\mathrm{h}}$ & $1.4^{\mathrm{def}}$ & $15.1^{\mathrm{fg}}$ & $20.9^{f}$ & $72.3^{\mathrm{g}}$ \\
\hline & $\mathrm{C}$ & $1.3^{\text {bcdef }}$ & $13.8^{\mathrm{e}}$ & $19.0^{\mathrm{e}}$ & $72.7^{\mathrm{g}}$ & $1.4^{\mathrm{def}}$ & $15.2^{\mathrm{f}}$ & $20.9^{f}$ & $72.6^{\mathrm{f}}$ \\
\hline \multirow{3}{*}{ Fennel } & $\mathrm{A}$ & $1.2^{\text {cdef }}$ & $13.8^{\mathrm{e}}$ & $19.0^{\mathrm{e}}$ & $72.7^{\mathrm{g}}$ & $1.4^{\mathrm{def}}$ & $15.5^{\mathrm{e}}$ & $21.3^{\mathrm{e}}$ & $72.7^{\mathrm{f}}$ \\
\hline & $\mathrm{B}$ & $1.3^{\text {bcdef }}$ & $13.9^{\mathrm{e}}$ & $19.0^{\mathrm{e}}$ & $73.0^{f}$ & $1.4^{\text {cde }}$ & $15.6^{\mathrm{e}}$ & $21.4^{\mathrm{e}}$ & $72.9^{e}$ \\
\hline & $\mathrm{C}$ & $1.3^{\text {bcde }}$ & $14.2^{\mathrm{d}}$ & $19.4^{\mathrm{d}}$ & $73.3^{\mathrm{e}}$ & $1.5^{\mathrm{bcd}}$ & $15.8^{\mathrm{d}}$ & $21.6^{\mathrm{d}}$ & $73.0^{\mathrm{e}}$ \\
\hline \multirow{3}{*}{ Rosemary } & $\mathrm{A}$ & $1.3^{\mathrm{bcd}}$ & $14.8^{\mathrm{c}}$ & $19.8^{\mathrm{c}}$ & $74.6^{\mathrm{d}}$ & $1.6^{\mathrm{abc}}$ & $16.4^{\mathrm{c}}$ & $22.3^{\mathrm{bc}}$ & $73.4^{\mathrm{d}}$ \\
\hline & $\mathrm{B}$ & $1.4^{\mathrm{bc}}$ & $14.9^{\mathrm{bc}}$ & $19.9^{\mathrm{bc}}$ & $74.8^{\mathrm{c}}$ & $1.6^{\mathrm{ab}}$ & $16.4^{\mathrm{c}}$ & $22.2^{\mathrm{c}}$ & $73.7^{\mathrm{c}}$ \\
\hline & $\mathrm{C}$ & $1.4^{\mathrm{b}}$ & $15.0^{\mathrm{b}}$ & $20.0^{\mathrm{b}}$ & $75.0^{\mathrm{b}}$ & $1.7^{\mathrm{a}}$ & $16.6^{\mathrm{b}}$ & $22.5^{\mathrm{b}}$ & $73.9^{b}$ \\
\hline \multicolumn{2}{|c|}{ Domark (10\% EC) } & $1.7^{\mathrm{a}}$ & $16.9^{\mathrm{a}}$ & $22.5^{\mathrm{a}}$ & $75.2^{\mathrm{a}}$ & $1.7^{\mathrm{a}}$ & $17.8^{\mathrm{a}}$ & $24.6^{\mathrm{a}}$ & $74.2^{\mathrm{a}}$ \\
\hline \multicolumn{2}{|c|}{ Control } & $0.5^{\mathrm{h}}$ & $9.4^{j}$ & $17.5^{i}$ & $53.6^{1}$ & $0.6^{\mathrm{h}}$ & $9.8^{j}$ & $17.3^{\mathrm{h}}$ & $56.7^{1}$ \\
\hline
\end{tabular}

* Solvent: Petroleum ether (A), Chloroform (B), Ethanol (C). • Duncan's multiple range tests was usedvalues followed by the different letters are significantly differed from each other. 
Table 5. Effect of plant extracts with different organic solvents on some crop parameters of sugar beet in Giza governorate

\begin{tabular}{|c|c|c|c|c|c|c|c|c|c|}
\hline \multirow[b]{2}{*}{ Treatment } & \multirow{2}{*}{$\begin{array}{l}\stackrel{*}{*} \\
\stackrel{D}{D} \\
\frac{1}{0} \\
\stackrel{0}{\circ}\end{array}$} & \multicolumn{4}{|c|}{ 2013/14 Season } & \multicolumn{4}{|c|}{ 2014/15 Season } \\
\hline & & $\begin{array}{c}\text { Root weight } \\
(\mathrm{Kg})\end{array}$ & $\begin{array}{c}\text { Sucrose } \\
(\%)\end{array}$ & $\begin{array}{c}\text { T.S.S } \\
(\%)\end{array}$ & $\begin{array}{c}\text { Purity } \\
(\%)\end{array}$ & $\begin{array}{c}\text { Root } \\
\text { weight }(\mathrm{Kg})\end{array}$ & $\begin{array}{c}\text { Sucrose } \\
(\%)\end{array}$ & \begin{tabular}{|c|} 
T.S.S \\
$(\%)$
\end{tabular} & $\begin{array}{c}\text { Purity } \\
(\%)\end{array}$ \\
\hline \multirow{3}{*}{ Marjoram } & A & $1.3^{\mathrm{d}}$ & $13.8^{j}$ & $19.1^{\mathrm{j}}$ & $72.1^{i}$ & $1.4^{\mathrm{f}}$ & $14.1^{j}$ & $19.8^{\mathrm{j}}$ & $71.2^{\mathrm{g}}$ \\
\hline & B & $1.3^{\mathrm{d}}$ & $13.0^{1}$ & $17.9^{1}$ & $72.4^{\mathrm{h}}$ & $1.4^{\mathrm{f}}$ & $14.2^{\mathrm{j}}$ & $19.9^{\mathrm{j}}$ & $71.3^{\mathrm{g}}$ \\
\hline & $\mathrm{C}$ & $1.3^{\mathrm{d}}$ & $13.4^{\mathrm{k}}$ & $18.4^{\mathrm{k}}$ & $72.7^{\mathrm{g}}$ & $1.4^{\mathrm{ef}}$ & $14.4^{\mathrm{i}}$ & $20.2^{\mathrm{i}}$ & $71.3^{\mathrm{g}}$ \\
\hline \multirow{3}{*}{ Thyme } & $\mathrm{A}$ & $1.4^{\mathrm{cd}}$ & $14.5^{i}$ & $19.7^{i}$ & $73.6^{f}$ & $1.4^{\mathrm{def}}$ & $14.7^{\mathrm{h}}$ & $20.4^{\mathrm{h}}$ & $71.9^{f}$ \\
\hline & B & $1.4^{\mathrm{cd}}$ & $14.6^{\mathrm{i}}$ & $19.8^{\mathrm{i}}$ & $73.6^{\mathrm{f}}$ & $1.5^{\mathrm{def}}$ & $14.8^{\mathrm{h}}$ & $20.5^{\mathrm{h}}$ & $72.0^{\mathrm{ef}}$ \\
\hline & $\mathrm{C}$ & $1.4^{\mathrm{cd}}$ & $14.8^{\mathrm{h}}$ & $20.0^{j}$ & $73.9^{\mathrm{e}}$ & $1.5^{\text {cdef }}$ & $15.0^{\mathrm{g}}$ & $20.8^{\mathrm{g}}$ & $72.1^{\mathrm{e}}$ \\
\hline \multirow{3}{*}{ Fennel } & $\mathrm{A}$ & $1.5^{b c}$ & $15.9^{\mathrm{g}}$ & $21.2^{\mathrm{g}}$ & $74.8^{\mathrm{d}}$ & $1.5^{\text {bcdef }}$ & $15.3^{f}$ & $21.1^{\mathrm{f}}$ & $72.6^{\mathrm{d}}$ \\
\hline & B & $1.5^{\mathrm{bc}}$ & $16.2^{\mathrm{f}}$ & $21.6^{\mathrm{f}}$ & $74.8^{\mathrm{d}}$ & $1.5^{\text {bcdef }}$ & $15.6^{\mathrm{e}}$ & $21.4^{\mathrm{e}}$ & $72.7^{\mathrm{d}}$ \\
\hline & $\mathrm{C}$ & $1.5^{\mathrm{bc}}$ & $16.4^{\mathrm{e}}$ & $21.9^{\mathrm{e}}$ & $74.9^{\mathrm{d}}$ & $1.5^{\text {bcde }}$ & $15.8^{\mathrm{d}}$ & $21.7^{\mathrm{d}}$ & $72.9^{c}$ \\
\hline \multirow{3}{*}{ Rosemary } & $\mathrm{A}$ & $1.5^{\mathrm{abc}}$ & $16.7^{\mathrm{d}}$ & $22.1^{\mathrm{d}}$ & $75.4^{\mathrm{c}}$ & $1.6^{\mathrm{abcd}}$ & $16.5^{\mathrm{c}}$ & $22.2^{\mathrm{c}}$ & $74.3^{b}$ \\
\hline & B & $1.6^{\mathrm{ab}}$ & $16.9^{c}$ & $22.3^{c}$ & $75.7^{\mathrm{b}}$ & $1.6^{\mathrm{abc}}$ & $16.5^{\mathrm{c}}$ & $22.2^{\mathrm{c}}$ & $74.3^{\mathrm{b}}$ \\
\hline & $\mathrm{C}$ & $1.6^{\mathrm{ab}}$ & $17.1^{\mathrm{b}}$ & $22.6^{\mathrm{b}}$ & $75.7^{\mathrm{b}}$ & $1.7^{\mathrm{ab}}$ & $16.7^{\mathrm{b}}$ & $22.4^{\mathrm{b}}$ & $74.4^{\mathrm{b}}$ \\
\hline \multicolumn{2}{|c|}{ Domark $(10 \% \mathrm{EC})$} & $1.6^{\mathrm{a}}$ & $17.6^{\mathrm{a}}$ & $23.0^{\mathrm{a}}$ & $76.5^{\mathrm{a}}$ & $1.7^{\mathrm{a}}$ & $17.2^{\mathrm{a}}$ & $22.8^{\mathrm{a}}$ & $75.5^{\mathrm{a}}$ \\
\hline \multicolumn{2}{|c|}{ Control } & $0.8^{\mathrm{e}}$ & $10.3^{\mathrm{m}}$ & $16.61^{\mathrm{m}}$ & $62.0^{j}$ & $0.69^{g}$ & $9.7^{\mathrm{k}}$ & $17.8^{\mathrm{k}}$ & $54.6^{\mathrm{h}}$ \\
\hline
\end{tabular}

(*) as described in footnote of Table (4).

\section{D i s c us s i o n}

Reduction of sugar beet cultivars to powdery mildew disease were differed under natural infection on filed. The observed differences may be due to genetic background of cultivars. In this investigation, results showed that the application of organic solvent extracts of four medicinal and aromatic plants reduced the disease incidence and disease severity of sugar beet powdery mildew disease. Some plants may be alternatives to currently used disease control agents since they constitute rich source of bioactive chemicals. Plants synthesize secondary metabolites and some of them as well as their derivatives have antimicrobial effect. Among these secondary metabolites are alkaloids, flavonoids, isoflavonoids, tannins, cumarins, glycosides, terpens and phenolic compounds. These compounds have broad-spectrum activities against fungi, nematodes and insects (Wilson et al., 1997 and Calvet et al., 2001).

Among all organic solvents tested, ethanol extract of the four medicinal and aromatic plants was the most effective one in controlling powdery mildew disease. The most identified antimicrobial compounds from aromatic plants were obtained through initial ethanol or methanol extraction (Malkhan et al., 2012). The phytochemical toxicity of plant extracts to microorganisms may be due to enzyme inhibition by the oxidized compounds, possibility through reaction with sulfhydryl groups or through more non-specific interactions with the protein. Seint and Masara (2011) reported that, rosemary is one of the best sources of phytochemicals to control Rhizoctonia solani and $R$. oryzae. The antimicrobial efficacy of rosemary was associated with their specific phenolic composition, mainly carnosic acid, carnosol and rosmarinic acid by some unknown mechanism (Moreno et al., 2006).

Abd El-Khair and Haggag (2007) reported that, aqueous extract of marjoram leaves decreased the spore germination (\%) of Phytophthora infestans and 
Alternaria solani comparing to the control. The aqueous and alcoholic seed extracts of fennel showed antifungal activity against Alternaria alternata, Mucor reuxii and Aspergillus flavus (Neetu et al., 2013). El-Mougy and Mokhtar (2007) evaluated twenty powdered spice plants and their ethanol extract against some soil borne fungi causing faba bean damping-off disease. Extract of Thyme, Garlic and Cinnamon were more effective on reducing the damping-off disease. The results of this study may form the basis for the development of eco-friendly natural fungicides for the management of sugar beet powdery mildew disease. Usage of aromatic and medicinal plants extracts might be considered as safe, cheap and easily applied method to avoid the environmental pollution and side effects of pesticide application.

\section{R e f e r e n c e s}

Abd El-Khair, H. and Haggag, Wafaa M. 2007. Application of some Egyptian medicinal plant extracts against potato late and early blights. Res. J. Agric. Biol. Sci., 3(3):166 -175.

Alsurhanee, Ameena M. 2013. Efficiency of the extracts of some plants on squash powdery mildew. Mediterranean J. Soc. Sci., 4(11): 39-49.

Anonymous 1990. Association Official Analytical Chemists (A.O.A.C). Official Methods Analytical Chemists. Washington, 25, D.C., USA.

Brimner, T.A. and Boland, G.A. 2003. A review of the non-target effects of fungi used to biologically control plant diseases. Agr. Ecosys. Environ., 100(1):3 -16.

Calvet, C.; Pinochet, J.; Camprubi, A.; Estaun, V. and Rodriguez-Kabana. 2001. Evaluation of natural chemical compounds against root lesion and root-knot nematodes and side-effects on the infectivity of arbuscular mycorrhizal fungi. European J. Pl. Pathol., 107: $601-605$.

El-Kholi, M. M. A. 2000. Sugar beet diseases in Egypt. Proceeding $9^{\text {th }}$ Congress of Egyptian Phytopathology Society, pp. $409-415$.

El-Mougy, Nehal S. and Abdel-Kader, M. M. 2007. Antifungal effect of powdered spices and their extracts on growth and activity of some fungi in relation to damping-off disease control. J. Plant Protect. Res., 47(3): 267 - 278.

Gado, E. A. M. 2013. Impact of treatment with some plant extracts and fungicides on sugar beet powdery mildew and yield components. Austral. J. Basic Applied Sci., $7(1): 468-472$.

Goussous, S. J.; Masad, L. S.; Abu El-Samen, F. M. and Tahlan, R. A. 2013. In vitro inhibitory effects of rosemary and sage extracts on mycelia growth and sclerotial formation and germination of Sclerotinia sclerotiorum. Arch. Phytopathol. Plant Prot., 1:1-13.

Malkhan, S. G.; Shahid, A.; Masood, A. and Kangabam, S. S. 2012. Efficacy of plant extracts in plant disease management. Agric. Sci. J., 3: $425-433$.

McGinnis, R. A. 1982. Beet sugar technology $3^{\text {rd }}$ Ed. Beet sugar development for Collins. p. 855. 
Moreno, S.; Scheyer, T.; Romano, C. S. and Vosnov, A. A. 2006. Antioxidant and antimicrobial antibacterial activities of natural extracts linked to their polyphenol composition. Free Radic Res., 40(2): 223-231.

Neetu, T.; Niketa, S.; Bansuli, S. and Kritika, J. 2013. Studies on in vitro antifungal activity of Foeniculum vulgare Mill. against spoilage fungi. Global J. Bio-Sci. Bio Technol., 3: 427 - 430.

Ogobo, E. M. and Oyibo, A. E. 2008. Effects of three plant extracts (Ocimum gratissimum, Acalypha wilkesiana and Acalypha macrostachya) on post-harvest pathogen of Persea Americana. J. Med. Plants Res., 2: 311 - 314.

Seint, S. A. and Masaru, M. 2011. Effect of some plant extracts on Rhizoctonia spp. and Sclerotium hydrophilum. J. Medicinal Plants Res., 5(16): 3751 - 3757.

Whitney, E. D.; Lewellen, R. T. and Skoyen, I. O. 1983. Reaction of sugar beet to powdery mildew: Genetic variation, association among testing procedures and results breeding. Phytopathology, 73:182-185.

Wilson, C. L.; Solar, J. M.; El-Ghaouth, A. and Wisniewski, M. E. 1997. Rapid evaluation of plant extracts and essential oils for antifungal activity against Botrytis cinerea. Plant Dis., 81: $204-210$.

Winer, B .J.1971 "Statistical principle in experimental design". $2^{\text {nd }}$ Ed. (McGrawHill Kogakusha Ltd.Tokyo). 596 pp.

(Received 29/02/2016; in revised form 30/03/2016)

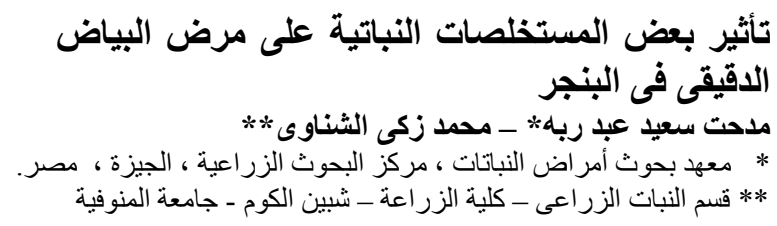

تمت دراسة فاعلية استخدام مستخلصات أربعة نباتات طبية وعطرية

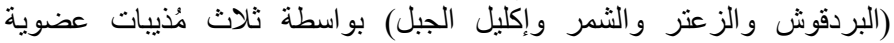

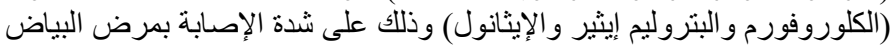

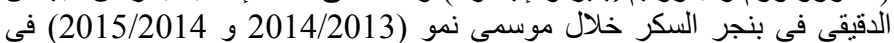

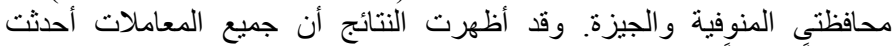

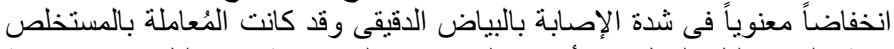

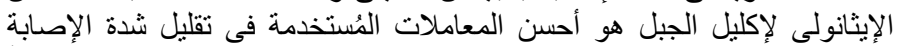

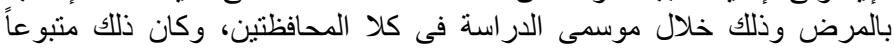

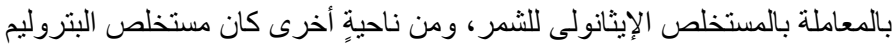

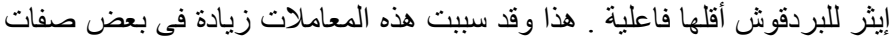

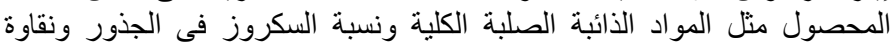

السكر وكذلك وزن الجذور ـ النوان

Egypt. J. Phytopathol., Vol. 44, No. 1 (2016) 